GRASAS Y ACEITES 69 (2)

April-June 2018, e251

ISSN-L: 0017-3495

https://doi.org/10.3989/gya.1216172

\title{
Zero trans biscuits with soybean-based fats formulated using an artificial neural network
}

\author{
A.A.T. Penteado ${ }^{\text {a }}$, A.C. Nogueira ${ }^{\mathrm{a}}$, K.M.B. Gandra ${ }^{\mathrm{b}}$, D. Barrera-Arellano ${ }^{\mathrm{a}}$, C.J. Steel ${ }^{\mathrm{a}, \bigotimes}$ \\ ${ }^{\text {a } D e p a r t m e n t ~ o f ~ F o o d ~ T e c h n o l o g y, ~ S c h o o l ~ o f ~ F o o d ~ E n g i n e e r i n g, ~ U n i v e r s i t y ~ o f ~ C a m p i n a s, ~ Z i p ~ C o d e ~ 13083-862, ~ C a m p i n a s, ~ S P, ~ B r a z i l . ~}$ \\ ${ }^{b}$ Food Department, School of Nutrition, Federal University of Ouro Preto, Zip Code 35400-000, Ouro Preto, MG, Brazil. \\ ${ }^{\otimes}$ Corresponding author: steel@unicamp.br
}

Submitted: 01 December 2017; Accepted: 12 February 2018

SUMMARY: This study applied Artificial Neural Network (ANN) technology to formulate zero trans fat blends derived from soybeans and to evaluate their performance when applied to the processing of sweet laminated biscuits. For the formulation of the blends, two interesterified soybean fats and soybean oil were used as bases. They were characterized in terms of melting point, solid fat content and fatty acid composition; and the biscuits produced were analyzed for their technological (dimensions, mass, volume, expansion, instrumental color and texture, moisture gradient and cracking) and physicochemical characteristics (total fat and moisture contents, water activity and fatty acid composition). It was possible to verify the use of ANN to develop zero trans fats derived from soybeans for application in sweet laminated biscuits, which represents an operational and financial advantage. Moreover, we showed the viability of using soybean fats/oil, raw materials of greater availability and lower cost, for the production of biscuits.

KEYWORDS: Cookie; Interesterified fat; Marie-type; Neural network; Trans fat

RESUMEN: Galletas con grasas cero trans a base de soja formuladas usando una red neuronal artificial. Este estudio aplicó la tecnología de Redes Neuronales Artificiales (RNA) para formular mezclas de grasas cero trans derivadas de soja y evaluar su papel cuando se usan en el procesamiento de galletas dulces laminadas. Para la formulación de las mezclas se usaron como base dos grasas de soja interesterificadas así como aceite de soja. Se caracterizaron en términos de punto de fusión, contenido de grasa sólida y composición de ácidos grasos, y a las galletas se les determinó sus características tecnológicas (dimensiones, masa, volumen, color, textura, gradiente de humedad así como otros controles) y fisicoquímicas (contenidos de grasa total, humedad, actividad de agua y composición de ácidos grasos). Fue posible verificar el uso de RNA para desarrollar grasas cero trans derivadas de soja, para su aplicación en galletas dulces laminadas, lo que representa una ventaja operativa y financiera. Además, mostramos la viabilidad de usar grasas/aceite de soja, materias primas de mayor disponibilidad y menor costo, para la producción de galletas.

PALABRAS CLAVE: Cookie; Grasa interesterificada; Grasas trans; Red neuronal; Tipo María

ORCID ID: Penteado AAT https://orcid.org/0000-0003-1030-7076, Nogueira AC https://orcid.org/0000-0002-14505574, Gandra KMB https://orcid.org/0000-0002-7934-9218, Barrera-Arellano D https://orcid.org/0000-0002-82178392, Steel CJ https://orcid.org/0000-0002-0911-5889

Citation/Cómo citar este artículo: Penteado AAT, Nogueira AC, Gandra KMB, Barrera-Arellano D, Steel CJ. 2018. Zero trans biscuits with soybean-based fats formulated using an artificial neural network. Grasas Aceites 69 (2), e251. https://doi.org/10.3989/gya.1216172

Copyright: $(2018$ CSIC. This is an open-access article distributed under the terms of the Creative Commons Attribution 4.0 International (CC BY 4.0) License. 


\section{INTRODUCTION}

Fats are widely used in the food industry, and over the last years, their development has required an increasingly higher specialization for the production of fats with physicochemical properties defined according to their application. Moreover, the controversy about the effects of the consumption of trans fatty acids for human health represents a challenge, with companies being required to produce fats and shortenings with reduced formation of trans fatty acids (Garcia et al., 2013), healthier formulations that present the same functionality and economic viability, with a reduced amount of saturated fatty acids (Ribeiro et al., 2007; Dhaka et al., 2011; Doan et al., 2018).

The production of these fats using different raw materials, which are blended in different proportions, still depends on formulators that use multiple trial-and-error procedures (Block et al., 1997; García et al., 2012). These formulators, generally based on the melting point (MP) and solid fat content (SFC) of the raw materials available and on the product to be formulated, determine the proportion of each raw material in the blend, in some cases with statistical methods, such as linear programming or databases. In general, it is possible to say that these methods are not very precise, do not consider cost optimization and mostly depend on the experience of the formulator. In other words, the conventional procedure for the formulation of fats involves a lengthy and demanding process (Ghotra et al., 2002). In addition, there are also economic issues related to the availability of raw materials which can cause significant financial impacts depending on price fluctuations (García et al., 2012).

In this scenario, Artificial Neural Networks (ANNs) can represent an alternative. They are very useful computational techniques when precise mathematical information is not available, in addition to being able to solve linear and non-linear problems. The network is composed of processing layers called artificial neurons (Cerqueira et al., 2001), which receive signals and pass them on to the intermediate layers of the program through mathematical connections. Each neuron processes part of the information, which occurs in parallel, and automatically distributes it through the different units that compose the network. The processing units transfer the weighted sums of information through an activation function, usually sigmoidtype, which contains a large number of informative signals that are converted into values defined during the training operation and the test (Sousa et al., 2003). According to Block et al. (1999), the incorporation of neural networks into the industrial process enables more automation and reduces the laboratorial work necessary for formulations using conventional methods. Moreover, since they offer multiple solutions for each product, they can be very useful for research and development (Block et al., 2003), including the formulation of fats, enhancing the performance of interesterified fats in the final product (Block et al., 1999; García et al., 2013).

Innovations in the development of fats for biscuit dough have also followed the tendency of reducing saturated and trans fats, with the aim of maintaining the same performance (Grimaldi and Gonçalves, 2009). Since fat is considered one of the most important ingredients in biscuit production (Manley, 2000; Moretto and Fett, 1999), this becomes a great challenge. Moreover, it has multifaceted functions, being responsible for imparting shortening, richness, and tenderness, and to improve flavor and sensation in the mouth (Pareyt and Delcour, 2008). The presence of fat in the dough results in eating properties after baking that are described as less hard, shorter and more inclined to melt in the mouth. If the fat level is high, the lubricating function in the dough is so pronounced that little or no water is required to achieve a desired consistency, little or no gluten is formed and starch swelling and gelatinization are also reduced, resulting in a very soft texture. The dough breaks easily when pulled because it is short (Manley, 2000). Fat also has the function of enhancing aeration for leavening and volume, influencing the density and texture of the dough, in addition to affecting heat transfer and spreading (more easily spread with more fat) (Manley, 2000; Lai and Lin, 2006; Pareyt and Delcour, 2008). To complete its wide range of functions, the influence on the structural integrity and the shelf life of the product can be determined (Ghotra et al., 2002; Lai and Lin, 2006).

In most formulations from the Brazilian market, trans fat is mostly substituted by palm fat or blends of interesterified fat of soybean/cottonseed with palm fat, which excessively raises the price of the final product because of the high economic value of palm fat. Since national production does not cover the needs of the country, it must be imported. Moreover, it has been widely used in the biodiesel market, reducing its availability for foods and increasing its costs. As a result, the use of fats that derive solely from soybean would bring about economic advantages and less concerns about the availability of the product in the country. According to Garcia et al. (2013), the success of the reduction or elimination of trans fatty acids can include the interesterification of soybean-based fats, which are abundant in Brazil.

Thus, this study aimed to evaluate the performance of low trans fats derived from soybean and formulated using an Artificial Neural Network (ANN) in sweet laminated biscuits (Marie-type). 


\section{MATERIALS AND METHODS}

\subsection{Materials}

To formulate the fat blends using the neural network, we used soybean-based interesterified fat with $40 \%$ soybean oil and $60 \%$ fully hydrogenated soybean oil - Base 1 (B1) (Triângulo Alimentos, Itápolis, Brazil), soybean-based interesterified fat with $70 \%$ soybean oil and 30\% fully hydrogenated soybean oil - Base 2 (B2) (Triângulo Alimentos, Itápolis, Brazil) and Liza refined soybean oil (SO) (Cargill Agrícola S/A, Mairinque, Brazil).

To compare the elaboration and the quality of the laminated biscuits, the following commercial fats were used: interesterified low trans fat (LTF) TRI HS-LT and partially hydrogenated vegetable fat (HSF) TRI ICE PLUS, called Standard 1 and 2, respectively, both from Triângulo Alimentos Ltda. (Itápolis, Brazil).

The remaining ingredients used to elaborate the laminated biscuits were: Probisc 75 wheat flour (Bunge Alimentos S.A., Tatuí, Brazil), powdered sugar (Harald Indústria e Comércio de Alimentos Ltda., Santana de Parnaíba, Brazil), corn starch (Corn Products, Mogi Guaçu, Brasil), União Pró inverted sugar syrup (Indústria Nova América S.A., Tarumã, Brazil), SOLEC SG IP soy lecithin (Solae do Brasil Ind. Com. Alim. Ltda., Barueri, Brazil), Lebre iodized salt (Norte Salineira AS Ind. e Com., Areia Branca, Brasil), ammonium bicarbonate and sodium bicarbonate distributed by the company Docepan Dist. de Prod. Alimentícios Ltda., sodium acid pyrophosphate (SAPP) (ICL Brasil Ltda., São José dos Campos, Brazil), Prata vanilla flavor (Iceberg Ind. e Com. Ltda., Jandira, Brazil) and Alfa sodium metabisulphite (Plury Química Ltda., Diadema, Brazil).

\subsection{Methods}

\subsubsection{Production of the blends using the neural network}

To define the formulation of the fat blends to be used in the laminated biscuits, the search for approximate solutions with the neural network was performed to obtain blend formulations with melting point (MP) and solid fat curve (SFC) values close to the values of commercial fats used in biscuits as standard fats (hydrogenated and low trans). From the 10 responses provided by the network (Gandra, 2011), four blend formulations were selected according to the technical criteria of lower total error with respect to the indicated profile. These formulations were prepared at lab-scale and characterized for application in laminated biscuits. The preparation of the blends was carefully made to ensure the homogeneity of the fats before they were weighed and mixed. For that purpose, the process of weighing and mixing was applied to melted fats.

\subsubsection{Characterization of the blends}

The melting point, solid fat content and fatty acid composition of the blends were analyzed according to the methods described below.

Melting point (MP). To determine the melting point, the methodology by Karabulut et al. (2004) was used. It defines melting point as the temperature at which the fat presents $4 \%$ of solids in the determination of the SFC.

Solid fat content (SFC). The solid fat content was determined using a nuclear magnetic resonance spectrometer - Bruker NMR Analyzer Mq 20 (Bruker, USA) - with Duratech TCON dry bath, following the AOCS Cb 16b-93 Method (2005). The direct method included tempering non-stabilized fats, readings of the samples in series, at the temperatures of $10,20,25,30,35,40$ and $45^{\circ} \mathrm{C}$, with initial tempering $\left(105^{\circ} \mathrm{C}\right.$ for $15 \mathrm{~min}, 2 \mathrm{~h}$ at $\left.0{ }^{\circ} \mathrm{C}\right)$ and 60 minutes for each temperature reading.

Fatty acids composition. The theoretical composition of the fatty acids of the formulated blends, as well as the amount of saturated, monounsaturated, polyunsaturated and trans fatty acids, were calculated from the fatty acid composition of the raw materials (Gandra, 2011), considering the percentage of each raw material used in the formulations of the blends.

\subsubsection{Elaboration of the biscuits}

Formulation. The formulation of Bernussi et al. (1998), with some adaptations made to fit the current practices of the biscuit industry and the purpose of this study, was used (in flour basis): wheat flour $(100 \%)$, sugar $(32.5 \%)$, water $(30 \%)$, corn starch $(20 \%)$, fat $(11 \%)$, inverted sugar $(10 \%)$, soy lecithin $(1.5 \%)$, salt $(1.25 \%)$, ammonium bicarbonate $(0.75 \%)$, sodium acid pyrophosphate $(0.74 \%)$, sodium bicarbonate $(0.55 \%)$, vanilla flavor $(0.5 \%)$ and sodium metabisulphite $(0.09 \%)$. The fats used for each of the seven tests were: Standard 1 and 2, soybean oil, and the 4 blends that were previously selected.

Process. The ingredients previously weighed were directly added to a KitchenAid mixer model BEA52ABAIN (Whirlpool Co., São Paulo, Brazil), with the bicarbonates being added last. It is worth noting that the fat was added at a temperature of $31 \pm 2{ }^{\circ} \mathrm{C}$. The mixing lasted 9 minutes, and at every minute it was stopped to remove dough from the sides of the bowl. The mixing speed was increased progressively: it started at the lowest speed of the 
mixer, and after one minute it was raised to speed 4, then at 3 minutes to speed 5 , at 5 minutes to speed 7 , and at 8 minutes to speed 9 . Then, the dough was covered with a polyethylene bag and left on a marble countertop for 35 minutes. The next step was lamination. First, the dough was put into an automatic cylinder CLA-600 (Progresso, Paraná, Brazil) on setting 1, and then into a manual cylinder Atlas 180 (Marcato, Italy) on settings 2 and 3, until the final thickness of $1.7 \pm 0.3 \mathrm{~mm}$ was obtained. Then, the laminated dough was spread over a stainless steel table and cut with a round Marie-biscuit mold (Graver, São Paulo, Brazil), with a diameter of $5.5 \mathrm{~cm}$. The remaining dough was put into the cylinders once again. The formatted biscuit doughs were transported to perforated stainless steel trays, carefully using a spatula to prevent any deformation. The biscuits were baked in an electric oven EC3 (Prática Technicook, Pouso Alegre, Brazil), preheated at $150{ }^{\circ} \mathrm{C}$ for 13 minutes. Lastly, the biscuits were cooled for 15 minutes at room temperature, avoiding air currents. Then, they were manually packaged in tinfoil and then in a thermo-sealed metalized BOPP film provided by the company Cepalgo Embalagens Flexíveis Ltda. (Aparecida de Goiânia, Brazil), using a bag sealer - model P60I (Proels, Marília, Brazil).

\subsubsection{Evaluation of the quality of the laminated biscuits}

The following aspects of the laminated biscuits were analyzed: mass and dimension characteristics (diameter, thickness, expansion factor, mass, volume and density), moisture content, moisture gradient, cracking, water activity, instrumental texture, instrumental color, total fat and fatty acid composition, according to the methods described below.

Diameter, thickness, volume, density and expansion of the biscuits. All dimensions of 10 biscuits produced with the different fats, equally positioned on the trays and in the oven, were measured with a caliper. The diameter and the thickness of the biscuits were measured before and after being put in the oven. The volume was calculated theoretically with the equation for the volume of a cylinder: $V=$ thickness $\times \pi$ $\times(\text { diameter } / 2)^{2}$. The density was determined by the ratio between the mass of the baked and cooled biscuit $(\mathrm{g})$ and its volume $\left(\mathrm{cm}^{3}\right)$. The expansion factor was expressed as the ratio between the diameter and the thickness of the biscuits (Bernussi et al., 1998).

Total fat. The total fat of the biscuits was extracted with petroleum ether in a Soxhlet extractor. The solvent was removed by evaporation, and the extract was weighed, as described in the AACCI method 30-10 (2010). The sample was ground for the analyses, which were performed in quadruplicate.
Moisture content. The moisture content of the biscuits was determined through AACCI method 44-15A (2010), in quadruplicate.

Instrumental texture. The hardness of the biscuit was determined with a TA-XT2i texture analyzer (Stable Micro Systems, England), using a platform with a circular opening, an accessory component of the device, and a Warner Blatzer blade. A test of compression force was performed, with a pre-test speed of $1.5 \mathrm{~mm} / \mathrm{s}$, test speed of $2.0 \mathrm{~mm} / \mathrm{s}$, post-test speed of $10.0 \mathrm{~mm} / \mathrm{s}$ and distance of penetration of $15.0 \mathrm{~mm}$ for a sampling of 10 biscuits.

Water activity $\left(\boldsymbol{a}_{w}\right)$. The amount of free water in the biscuits, in quadruplicate, was measured with an Aqualab device, model 3TE (Decagon, Washington, USA).

Instrumental color. The instrumental color was determined with a Hunter Lab colorimeter, model Color Quest XE (HunterLab, USA), using the CIELab system for 10 biscuits, by determining the values of $L^{*}, a^{*}, b^{*}$ and $\Delta \mathrm{E}$, where:

$$
\begin{aligned}
\Delta \mathrm{E} & =\left[\left(L^{*}{ }_{\text {control }}-L_{\text {assay }}^{*}\right)^{2}+\left(a_{\text {control }}^{*}-a_{\text {assay }}^{*}\right)^{2}\right. \\
& \left.+\left(b_{\text {control }}^{*}-b_{\text {assay }}^{*}\right)^{2}\right]^{1 / 2}
\end{aligned}
$$

Moisture gradient. The baked and cooled biscuits were submitted to a circular concentric cut, and the analysis of the moisture content of the central part and of the external ring was performed according to AACCI method 44-15A (2010). The moisture gradient was determined by the difference between the moisture content of the two parts. The analyses were conducted in quadruplicate, 24 hours after production.

Cracking. Cracking was evaluated with the visual observation of the biscuits (Bernussi et al., 1998), in a sampling of 10 biscuits. The percentage of the biscuits with cracks in them was calculated.

Fatty acid composition. The fatty acid composition of the lipid portion of the biscuits was determined through capillary-column gas chromatography. The methyl esters were prepared according to AOCS method Ce 2-66 (2005) and Hartman and Lago (1973). The operating conditions of the capillary-column gas chromatographer - CGC Agilent 6850 Series GC System (Agilent, China), with a DB-23 Agilent capillary column (50\% cyanopropyl-methylpolysiloxane, dimensions: length $=60 \mathrm{~m}$; inner diameter $=0.25 \mathrm{~mm}$; film thickness $=0.25 \mu \mathrm{m})$ were: oven temperature: $110{ }^{\circ} \mathrm{C}$ for $5 \mathrm{~min} ; 110$ to $215^{\circ} \mathrm{C}\left(5^{\circ} \mathrm{C} / \mathrm{min}\right) ; 214^{\circ} \mathrm{C}$ for $34 \mathrm{~min}$; temperature of the detector: $280^{\circ} \mathrm{C}$; temperature of the injector: $250{ }^{\circ} \mathrm{C}$; carrier gas: helium; split: 1:50; injected volume: $1.0 \mu \mathrm{L}$. The analysis was performed in triplicate. 


\subsubsection{Statistical analysis}

The statistical analysis was performed with the software SAS 9.2 - TS 2MO (SAS Institute Inc., NC, USA). The results obtained were evaluated by calculating means, standard deviations, analysis of variance (ANOVA) and multiple comparison of means using Tukey's test $(\mathrm{p} \leq 0.05)$.

\section{RESULTS AND DISCUSSION}

\subsection{Production of the blends}

The fat blends were produced using soybean oil (SO) and soybean-based interesterified fats (B1 and $\mathrm{B} 2$ ), in order to obtain a similar behavior to the solid fat content of commercial low trans fats (LTF), using a previously trained Artificial Neural Network (ANN). The network was trained with 62 samples, with the percentage of each raw material used in the formulations of the sample as input data, and the solid fat content and the melting point of the samples as output data (Gandra, 2011).

From this study, 10 responses were generated with the commercial low trans fat (LTF) as base. However, as it was observed that some solutions presented the same responses or very close responses, and they were categorized into four different groups (blends): BLD1 (6\% B1 + 34\% B2 + 60\% SO), BLD2 (13\% B1 $+19 \% \mathrm{~B} 2+68 \% \mathrm{SO}), \mathrm{BLD} 3(24 \% \mathrm{~B} 1+9 \% \mathrm{~B} 2+$ $67 \% \mathrm{SO})$ and BLD4 (0\% B1 + 46\% B2 + 54\% SO).

\subsection{Characterization of the blends}

The formulated blends were characterized according to their solid fat contents (Figure 1). As expected, the results of the solid curves showed that the blends presented very similar profiles, with only BLD3 presenting a higher percentage of solids for all temperatures. However, this percentage decreased much more for commercial fats than for the blends, especially from temperatures of 10 to $35^{\circ} \mathrm{C}$. In other words, while the solid fat content of commercial fats decreased by $85 \%$ when the temperature was increased in this range, the blends had a reduction of about $50 \%$. Between 35 and $45{ }^{\circ} \mathrm{C}$, the behavior of the curves of the blends was similar to that of the commercial fats, being closer to the LTF than to the HSF. As for the temperature of melting in the mouth $\left(37.5^{\circ} \mathrm{C}\right)$, the blends showed a percentage of solids $(\mathrm{BLD} 1=4.23 \%, \mathrm{BLD} 2=$ $4.24 \%, \mathrm{BLD} 3=5.73 \%$, BLD4 $=4.15 \%$ ) which was very close to that of the LTF $(4.50 \%)$, more than to the HSF $(6.73 \%)$. However, at room temperature $\left(25^{\circ} \mathrm{C}\right)$, the blends presented a percentage of solids $(\mathrm{BLD} 1=7.83 \%, \mathrm{BLD} 2=7.97 \%$, BLD3 $=10.65 \%$, BLD4 $=7.50 \%$ ), which was very different from both the LTF $(35.24 \%)$ and the HSF (16.61\%).

The melting point for each blend (BLD1, BLD2, BLD3 and BLD4) was 38.5, 38.0, 42.8 and $38.0^{\circ} \mathrm{C}$, respectively. With the exception of BLD3, the other blends presented almost identical melting points, since they had very close levels of saturated fatty

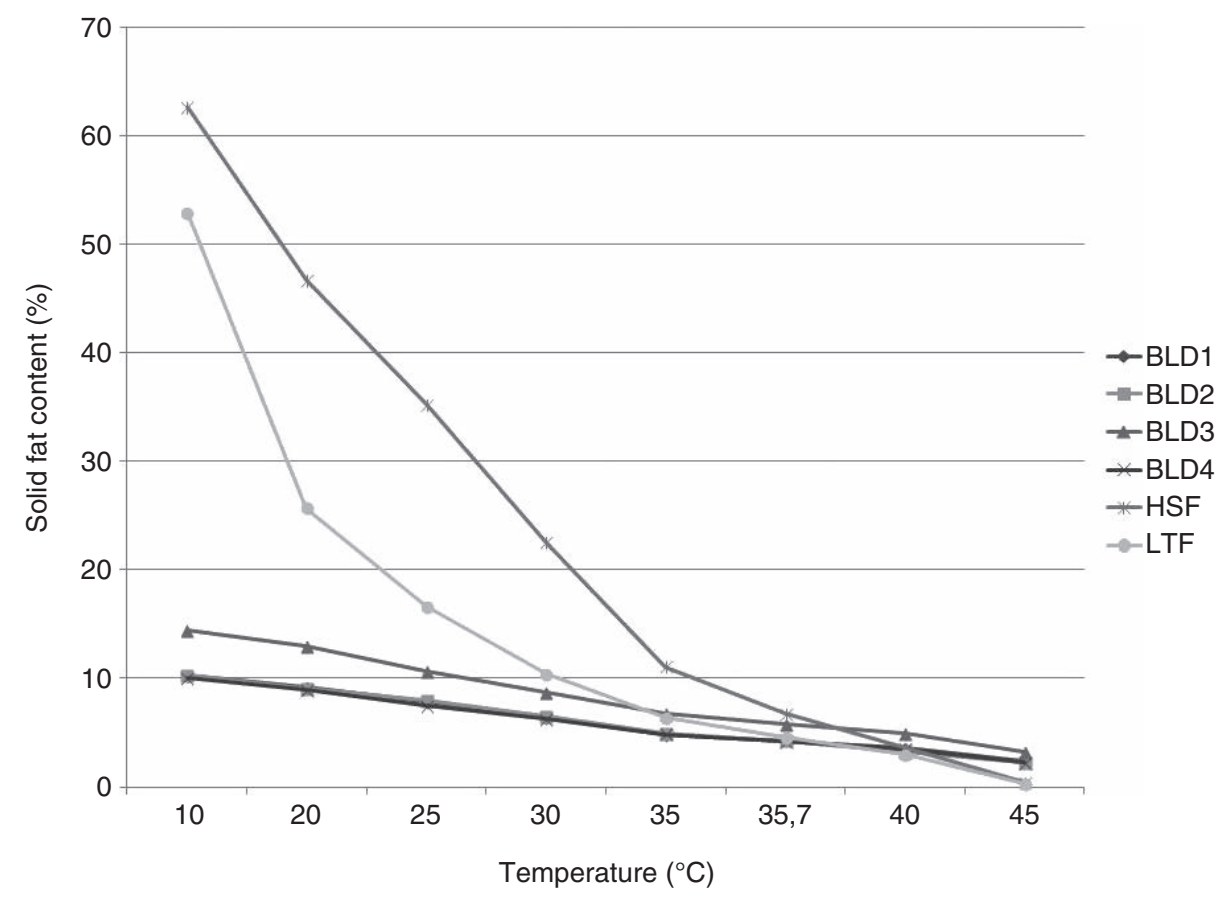

FIGURE 1. Solid fat content. LTF: low trans fat; HSF: hydrogenated soybean fat; BLD1: 6\% B1 + 34\% B2 + 60\% SO; BLD2: 13\% B1 + 19\% B2 + 68\% SO; BLD3: 24\% B1 + 9\% B2 + 67\% SO; BLD4: 0\% B1 + 46\% B2 + 54\% SO; B1: interesterified soybean-based fat with $40 \%$ soybean oil and $60 \%$ fully hydrogenated soybean oil; B2: interesterified soybean-based fat with $70 \%$ soybean oil and $30 \%$ fully hydrogenated soybean oil; SO: soybean oil; Number of replicates of analysis: 3 . 
acids (Table 1). Since BLD3 had the highest value of saturated fatty acids, it also presented the highest melting point of the blends. The blends had melting points closer to the $\operatorname{LTF}\left(38.3^{\circ} \mathrm{C}\right)$ than to the HSF $\left(39.5^{\circ} \mathrm{C}\right)$.

When we correlated the experimental values of the solid fat contents of the formulated blends with the values predicted by the neural network, it was

TABLE 1. Fatty acid composition, levels of saturated, unsaturated and trans fatty acids in the formulated blends

\begin{tabular}{|c|c|c|c|c|}
\hline & BLD1 & BLD2 & BLD3 & BLD4 \\
\hline C8:0 & 0.00 & 0.00 & 0.00 & 0.00 \\
\hline C10:0 & 0.00 & 0.00 & 0.00 & 0.00 \\
\hline C12:0 & 0.03 & 0.03 & 0.04 & 0.03 \\
\hline C14:0 & 0.10 & 0.10 & 0.10 & 0.10 \\
\hline C16:0 & 10.87 & 10.85 & 10.88 & 10.88 \\
\hline C16:1 trans & 0.09 & 0.09 & 0.09 & 0.09 \\
\hline C17:0 & 0.10 & 0.10 & 0.11 & 0.10 \\
\hline C18:0 & 14.22 & 13.94 & 16.86 & 14.25 \\
\hline C18:1 trans & 0.00 & 0.00 & 0.00 & 0.00 \\
\hline C18:1 & 24.61 & 25.06 & 24.13 & 24.34 \\
\hline C18:2 trans & 0.29 & 0.29 & 0.27 & 0.28 \\
\hline C18:2 & 43.11 & 42.97 & 41.21 & 43.33 \\
\hline C18:3 trans & 0.82 & 0.85 & 0.80 & 0.79 \\
\hline C18:3 & 4.47 & 4.43 & 4.25 & 4.51 \\
\hline C20:0 & 0.39 & 0.38 & 0.40 & 0.40 \\
\hline C20:1 & 0.06 & 0.04 & 0.04 & 0.07 \\
\hline C22:0 & 0.48 & 0.47 & 0.47 & 0.48 \\
\hline C24:0 & 0.19 & 0.19 & 0.19 & 0.19 \\
\hline Saturated & 26.38 & 26.07 & 29.04 & 26.43 \\
\hline Monounsaturated & 24.76 & 25.19 & 24.25 & 24.50 \\
\hline Polyunsaturated & 48.68 & 48.55 & 46.54 & 48.90 \\
\hline Total trans & 1.19 & 1.23 & 1.16 & 1.16 \\
\hline
\end{tabular}

BLD1: $6 \% \mathrm{~B} 1+34 \% \mathrm{~B} 2+60 \% \mathrm{SO} ; \mathrm{BLD} 2: 13 \% \mathrm{~B} 1+19 \%$ B2 + $68 \%$ SO; BLD3: $24 \%$ B1 + 9\% B2 + $67 \%$ SO; BLD4: $0 \%$ $\mathrm{B} 1+46 \% \mathrm{~B} 2+54 \% \mathrm{SO}$; B1: soybean-based interesterified fat with $40 \%$ soybean oil and $60 \%$ fully hydrogenated soybean oil; B2: soybean-based interesterified fat with $70 \%$ soybean oil and $30 \%$ fully hydrogenated soybean oil. The composition of the fatty acids of the formulated blends, as well as the amounts of saturated, monounsaturated, polyunsaturated and trans fatty acids, were calculated theoretically through the fatty acid composition of the raw materials (Gandra, 2011). This author performed the analyses in triplicate; using ANOVA and multiple comparison of means through Tukey's test and with a degree of significance of $\mathrm{p} \leq 0.05$. possible to observe that the network was capable of predicting the solid fat content and the melting point, since the values of the coefficients of determination $\left(\mathrm{R}^{2}\right)$ of the dispersion graphs (calculated output versus real output) were close to 1: 0.9911 for BLD1, 0.9907 for BLD2, 0.9977 for BLD3 and 0.9944 for BLD4. Garcia et al. (2013) also showed that neural networks were highly efficient in predicting the solid fat content and the melting point of blends elaborated with soybean-based interesterified fats.

Table 1 shows the theoretical fatty acid composition of the formulated blends, as well as the amounts of saturated, monounsaturated, polyunsaturated and trans fatty acids. This composition was calculated for each blend, based on the data presented by Gandra (2011) and on the percentages of each raw material used in their formulations.

BLD1, BLD2 and BLD4 blends had virtually identical fatty acid compositions and levels of saturated, unsaturated and trans fatty acids. The BLD3 blend, in turn, had a higher level of saturated fatty acids caused by the higher percentage of C18:0 in its composition. This occurred because this blend had a higher percentage of the interesterified base B1 in its composition, which had a higher level of stearic acid (C18:0) and a lower level of oleic acid (C18:1), unsaturated, when compared to interesterified base B2 and to soybean oil.

All the blends had a higher percentage of the same fatty acids in their composition, i.e., $42 \%$ linoleic acid, $24.5 \%$ oleic acid and $11 \%$ palmitic acid, for a total of $77.5 \%$. Once again, the blends were closer to the LTF, which was also composed mostly of these three fatty acids, but with different percentages for each of them $(9.2 \%$ linoleic acid, $41.9 \%$ oleic acid and $39.2 \%$ palmitic acid, for a total of $90.3 \%)$. The HSF, however, presented a different composition: oleic acid (30.5\%), elaidic acid $(24.7 \%)$ and stearic acid $(15.5 \%)$, for a total of $70.7 \%$ fatty acids in its composition. As for the trans fat content (Table 1), the blends also presented closer values to LTF $(1.0 \%)$, whereas HSF had a much higher content $(27.4 \%)$.

\subsection{Quality of the laminated biscuits}

Diameter, thickness, volume, density and expansion. The biscuits with no fat had the smallest diameter, while the biscuits with added commercial fats (LTF and HSF) presented the highest value, which showed the influence of fat on diameter (Table 2). As for the blends, in general they presented intermediate diameters, similar to those of biscuits with SO, except for BLD3, which had a smaller diameter. BDL4 biscuits also had a similar diameter to the biscuits with HSF.

As for thickness, only BLD4 differed from the other samples, showing that fat did not have a large influence on this parameter. Although differences 
TABLE 2. Diameter, thickness, volume, density and expansion of the biscuits produced with the different fats

\begin{tabular}{lccccc}
\hline & Diameter $(\mathbf{m m})$ & Thickness $(\mathbf{m m})$ & Volume $\left(\mathbf{c m}^{\mathbf{3}}\right)$ & Density $\left(\mathbf{g} / \mathbf{c m}^{\mathbf{3}}\right)$ & Expansion \\
\hline LTF & $57.1 \pm 0.6^{\mathrm{b}}$ & $4.3 \pm 0.29^{\mathrm{a}}$ & $10.8 \pm 0.8^{\mathrm{a}}$ & $0.42 \pm 0.02^{\mathrm{a}}$ & $13.3 \pm 0.7^{\mathrm{ab}}$ \\
HSF & $57.6 \pm 0.4^{\mathrm{a}}$ & $4.1 \pm 0.32^{\mathrm{c}}$ & $10.7 \pm 0.7^{\mathrm{a}}$ & $0.44 \pm 0.03^{\mathrm{a}}$ & $14.1 \pm 0.8^{\mathrm{ab}}$ \\
SO & $56.8 \pm 0.6^{\mathrm{c}}$ & $4.17 \pm 0.51^{\mathrm{abc}}$ & $10.5 \pm 1.2^{\mathrm{a}}$ & $0.45 \pm 0.04^{\mathrm{a}}$ & $13.7 \pm 1.4^{\mathrm{ab}}$ \\
NF & $56.0 \pm 0.5^{\mathrm{e}}$ & $4.28 \pm 0.30^{\mathrm{ab}}$ & $10.5 \pm 0.8^{\mathrm{a}}$ & $0.46 \pm 0.02^{\mathrm{a}}$ & $13.1 \pm 0.6^{\mathrm{b}}$ \\
BLD1 & $56.8 \pm 0.6^{\mathrm{c}}$ & $4.11 \pm 0.34^{\mathrm{c}}$ & $10.4 \pm 0.8^{\mathrm{a}}$ & $0.46 \pm 0.03^{\mathrm{a}}$ & $13.8 \pm 0.7^{\mathrm{ab}}$ \\
BLD2 & $56.7 \pm 0.5^{\mathrm{c}}$ & $4.16 \pm 0.57^{\mathrm{abc}}$ & $10.5 \pm 1.0^{\mathrm{a}}$ & $0.45 \pm 0.04^{\mathrm{a}}$ & $13.7 \pm 1.3^{\mathrm{ab}}$ \\
BLD3 & $56.3 \pm 0.4^{\mathrm{d}}$ & $4.2 \pm 0.42^{\mathrm{bc}}$ & $10.5 \pm 0.9^{\mathrm{a}}$ & $0.45 \pm 0.02^{\mathrm{a}}$ & $13.5 \pm 1.0^{\mathrm{ab}}$ \\
BLD4 & $56.8 \pm 0.4^{\mathrm{bc}}$ & $3.94 \pm 0.32^{\mathrm{d}}$ & $10.3 \pm 0.8^{\mathrm{a}}$ & $0.45 \pm 0.03^{\mathrm{a}}$ & $14.5 \pm 0.9^{\mathrm{a}}$ \\
\hline
\end{tabular}

Means in the same columns followed by identical letters do not differ significantly ( $\mathrm{p}<0.05)$. LTF: low trans fat; HSF: hydrogenated soybean fat; SO: soybean oil; NF: no fat; BLD1: $6 \%$ B1 + 34\% B2 + 60\% SO; BLD2: $13 \%$ B1 + 19\% B2 + 68\% SO; BLD3: $24 \%$ B1 + 9\% B2 + 67\% SO; BLD4: $0 \%$ B1 + 46\% B2 + 54\% SO; B1: interesterified soybean-based fat with $40 \%$ soybean oil and $60 \%$ fully hydrogenated soybean oil; B2: interesterified soybean-based fat with $70 \%$ soybean oil and 30\% fully hydrogenated soybean oil; Expansion: diameter/thickness. Number of replicates for each analysis: 10; Statistical test: ANOVA and multiple comparison of means using Tukey's test; Degree of significance: $\mathrm{p} \leq 0.05$.

were noticed in both parameters (diameter and thickness), the observed values of 56.0 to $57.6 \mathrm{~mm}$ and 3.94 to $4.30 \mathrm{~mm}$ (Table 2), respectively, did not vary much and remained within the quality standards for biscuits. According to an analysis of data from six brands of hard semisweet biscuits from the Brazilian market, their diameter varied by $9.14 \%$, while the thickness varied by $15.5 \%$, showing that these variations are accepted by the final consumer (Penteado and Steel, 2008).

Moreover, the difference in these parameters were not observed for the values of volume, density and expansion (Table 2), except when expansion was analyzed for the biscuits produced with no fat and with BLD4. The latter presented a higher expansion factor, which could be explained by the smaller final thickness of its biscuits. It is known that the volume and density of biscuits are important parameters for industries because they define the standardization of weight in the packages. Their dimensions are also relevant, affecting the sealing and consequently the final texture and the shelf life of the product (Manley, 2000).

Total fat content, moisture content, texture, water activity and color. Table 3 presents the results of all these parameters. For total fat, the biscuits produced with HSF presented a significant difference from the other biscuits, with the exception of the biscuits produced with soybean oil. Among the others, however, there were no significant differences.

For moisture content, the biscuits produced with the different blends and with LTF and HSF were not significantly different. The biscuits produced with $\mathrm{SO}$ and no fat (NF) showed a similar behavior, with higher moisture contents.

The results for instrumental texture confirmed the important function fat has on this parameter in the case of biscuits, since those produced with no fat were the only ones that differed from the others. The biscuits with no fat presented the highest value for hardness, proving that fat produces the desired softness and crunchiness, as stated by Grimaldi and Gonçalves (2009). Once again, since their results were similar to those of standard fats, the formulated blends could replace commercial fats with respect to the parameters of texture in the final product.

The water activity of the biscuits varied between 0.20 and 0.33 , remaining within the desirable range for biscuits. Thus, no significant interference of the fats and blends was observed for this parameter.

As for the color of the biscuits, there was no significant difference among the biscuits for parameter $L^{*}$, but for parameters $a^{*}$ and $b^{*}$, there was a significant difference between the biscuits produced with BLD3 and BLD1. Since the biscuits produced with no fat only differed significantly from the biscuits produced with HSF, it is not possible to affirm that color is a characteristic affected by fat in the case of biscuits. All the biscuits produced with the blends did not differ from LTF, thus color would not be a parameter of concern for the use of the formulated fat blends.

Another way to evaluate color is by means of the color variation parameter $(\Delta \mathrm{E})$, which demonstrates the color variation in relation to a control. Considering the two standard fats used in this study (LTF and HSF), calculations were made separately for each one. According to Francis and Clydesdale (1975), a value of $\Delta \mathrm{E}$ equal to or greater than two can be considered as a difference between two treatments perceptibly visible to the human eye. Therefore, in relation to LTF, only biscuits produced with BLD3 showed a noticeable difference in color. In relation to HSF, all biscuits were different, demonstrating that the biscuits produced with the blends (and biscuits without fat or with oil) were more similar to those with LTF. 
TABLE 3. Total fat, moisture content, texture, water activity and parameters of color of the biscuits produced with the different fats

\begin{tabular}{|c|c|c|c|c|c|c|c|c|c|}
\hline & \multirow[b]{2}{*}{ Total fat (\%) } & \multirow[b]{2}{*}{$\begin{array}{c}\text { Moisture } \\
\text { content (\%) }\end{array}$} & \multirow[b]{2}{*}{ Texture (N) } & \multirow[b]{2}{*}{$\mathbf{A}_{w}$} & \multicolumn{5}{|c|}{ Color } \\
\hline & & & & & $L^{*}$ & $a^{*}$ & $b^{*}$ & $\begin{array}{c}\Delta \mathrm{E}(\mathrm{LTF} \\
\text { as control) }\end{array}$ & $\begin{array}{c}\Delta \mathrm{E}(\mathrm{HSF} \\
\text { as control) }\end{array}$ \\
\hline LTF & $7.43 \pm 0.10^{b}$ & $4.04 \pm 0.04^{\mathrm{b}}$ & $48.90 \pm 12.85^{\mathrm{b}}$ & $0.30 \pm 0.02^{\mathrm{ab}}$ & $75.9 \pm 1.8^{\mathrm{a}}$ & $6.4 \pm 1.2^{\mathrm{ab}}$ & $29.2 \pm 1.6^{\mathrm{ab}}$ & 0.0 & 4.5 \\
\hline HSF & $8.42 \pm 0.10^{\mathrm{a}}$ & $3.65 \pm 0.05^{\mathrm{b}}$ & $49.84 \pm 5.75^{\mathrm{b}}$ & $0.26 \pm 0.01^{\mathrm{bc}}$ & $75.6 \pm 3.6^{\mathrm{a}}$ & $4.1 \pm 2.0^{\mathrm{c}}$ & $25.4 \pm 3.4^{\mathrm{c}}$ & 4.5 & 0.0 \\
\hline SO & $7.75 \pm 0.17^{\mathrm{ab}}$ & $4.89 \pm 0.14^{\mathrm{a}}$ & $37.42 \pm 5.85^{\mathrm{b}}$ & $0.31 \pm 0.01^{\mathrm{a}}$ & $74.5 \pm 2.6^{\mathrm{a}}$ & $5.9 \pm 1.3^{\mathrm{bc}}$ & $28.1 \pm 1.7^{\mathrm{bc}}$ & 1.8 & 3.4 \\
\hline NF & $0.98 \pm 0.07^{\mathrm{c}}$ & $5.40 \pm 0.02^{\mathrm{a}}$ & $88.23 \pm 13.90^{\mathrm{a}}$ & $0.33 \pm 0.01^{\mathrm{a}}$ & $75.6 \pm 2.3^{\mathrm{a}}$ & $6.7 \pm 1.1^{\mathrm{ab}}$ & $29.0 \pm 1.5^{\mathrm{ab}}$ & 0.5 & 4.4 \\
\hline BLD1 & $7.45 \pm 0.12^{\mathrm{b}}$ & $3.64 \pm 0.07^{\mathrm{b}}$ & $40.13 \pm 8.87^{\mathrm{b}}$ & $0.24 \pm 0.01^{\mathrm{cd}}$ & $76.0 \pm 3.0^{\mathrm{a}}$ & $5.9 \pm 1.9^{\mathrm{bc}}$ & $28.4 \pm 2.2^{\mathrm{b}}$ & 0.9 & 3.5 \\
\hline BLD2 & $7.58 \pm 0.43^{\mathrm{b}}$ & $3.64 \pm 0.19^{\mathrm{b}}$ & $50.94 \pm 14.08^{b}$ & $0.23 \pm 0.01^{\mathrm{cd}}$ & $75.5 \pm 3.1^{\mathrm{a}}$ & $6.7 \pm 2.0^{\mathrm{ab}}$ & $29.4 \pm 2.4^{\mathrm{ab}}$ & 0.5 & 4.8 \\
\hline BLD3 & $7.42 \pm 0.29^{\mathrm{b}}$ & $3.70 \pm 0.22^{\mathrm{b}}$ & $49.68 \pm 12.36^{\mathrm{b}}$ & $0.20 \pm 0.02^{\mathrm{d}}$ & $76.7 \pm 3.0^{\mathrm{a}}$ & $8.0 \pm 1.1^{\mathrm{a}}$ & $31.7 \pm 1.5^{\mathrm{a}}$ & 3.1 & 7.5 \\
\hline BLD4 & $7.21 \pm 0.43^{\mathrm{b}}$ & $4.07 \pm 0.59^{\mathrm{b}}$ & $48.37 \pm 9.70^{\mathrm{b}}$ & $0.24 \pm 0.01^{\mathrm{cd}}$ & $75.7 \pm 3.0^{\mathrm{a}}$ & $6.3 \pm 1.9^{\mathrm{ab}}$ & $29.0 \pm 2.2^{\mathrm{ab}}$ & 0.3 & 4.2 \\
\hline
\end{tabular}

Means in the same columns followed by identical letters do not differ significantly ( $\mathrm{p}<0.05)$. LTF: low trans fat; HSF: hydrogenated soybean fat; SO: soybean oil; NF: no fat; BLD1: $6 \%$ B1 + 34\% B2 + 60\% SO; BLD2: 13\% B1 + 19\% B2 + 68\% SO; BLD3: $24 \%$ B1 $+9 \%$ B2 + 67\% SO; BLD4: $0 \%$ B1 + 46\% B2 + 54\% SO; B1: interesterified soybean-based fat with $40 \%$ soybean oil and $60 \%$ fully hydrogenated soybean oil; B2: interesterified soybean-based fat with $70 \%$ soybean oil and $30 \%$ fully hydrogenated soybean oil; $\mathrm{A}_{\mathrm{w}}$ : water activity; $\Delta \mathrm{E}=\left[\left(L_{\text {control }}^{*}-L_{\text {assay }}^{*}\right)^{2}+\left(a_{\text {control }}^{*}-a_{\text {assay }}^{*}\right)^{2}+\left(b_{\text {control }}^{*}-b^{*}{ }_{\text {assay }}\right)^{2}\right]^{1 / 2}$. Number of replicates for moisture content and $A_{\mathrm{w}}$ analyses: 4; Number of replicates for texture and color parameters analyses: 10; Statistical test: ANOVA and multiple comparison of means using Tukey's test; Degree of significance: $\mathrm{p} \leq 0.05$.

Moisture gradient and percentage of cracking. The biscuits produced with no fat, with $\mathrm{SO}$ and with LTF presented the lowest percentages of moisture gradient, significantly different from those that presented higher moisture gradients (HSF, BLD1 and BLD3) (Table 4). The values obtained ranged between $0.14 \%$ and $0.46 \%$, with the smallest value referring to the biscuit with $\mathrm{SO}$ and the highest to that with HSF. For an efficient baking of biscuits, Smith (1972) recommends a moisture gradients in the order of $0.5 \%$, with values of up to $1 \%$ being tolerable, since the higher the value, the greater the risk of cracking. As the blends did not influence this parameter, they could replace commercial fats.

24 hours after their production, the biscuits with the highest percentage of cracking were those with soybean oil and with BLD1 (42\%). The biscuits with no fat had no percentage of cracking (Table 4). These results show the relationship between this parameter and texture because the biscuits with less cracking were those that presented the highest hardness, i.e., hard biscuits tend to present less cracking. However, a balance should be found since a pleasant texture should be obtained while reducing this percentage as much as possible. The blends BLD3 and BLD4 presented an intermediate percentage among the standard commercial fats.

Fatty acid composition. The fatty acid composition of the biscuits was virtually identical to the composition of the fat blends (Table 1), showing that the natural fat of wheat flour (approximately $1 \%$ ) and processing did not interfere with this parameter. The levels of total, saturated and trans fats for the biscuits produced with the blends are also shown in
TABLE 4. Moisture gradient and percentage of cracking in the biscuits produced with the different fats

\begin{tabular}{lcc}
\hline & Moisture gradient (\%) & Cracking (\%) \\
\hline LTF & $0.19 \pm 0.02^{\mathrm{b}}$ & 8 \\
HSF & $0.46 \pm 0.12^{\mathrm{a}}$ & 25 \\
SO & $0.14 \pm 0.01^{\mathrm{b}}$ & 42 \\
NF & $0.16 \pm 0.02^{\mathrm{b}}$ & 0 \\
BLD1 & $0.45 \pm 0.06^{\mathrm{a}}$ & 42 \\
BLD2 & $0.31 \pm 0.02^{\mathrm{ab}}$ & 25 \\
BLD3 & $0.40 \pm 0.01^{\mathrm{a}}$ & 17 \\
BLD4 & $0.31 \pm 0.01^{\mathrm{ab}}$ & 17
\end{tabular}

Means in the same columns followed by identical letters do not differ significantly $(\mathrm{p}<0.05$ ). LTF: low trans fat; HSF: hydrogenated soybean fat; SO: soybean oil; NF: no fat; BLD1: $6 \% \mathrm{~B} 1+34 \% \mathrm{~B} 2+60 \% \mathrm{SO} ; \mathrm{BLD} 2: 13 \% \mathrm{~B} 1+19 \% \mathrm{~B} 2+68 \%$ SO; BLD3: $24 \% \mathrm{~B} 1+9 \% \mathrm{~B} 2+67 \%$ SO $\mathrm{BLD} 4: 0 \% \mathrm{~B} 1+$ $46 \%$ B2 + 54\% SO; B1: interesterified soybean-based fat with $40 \%$ soybean oil and $60 \%$ fully hydrogenated soybean oil; B2: interesterified soybean-based fat with $70 \%$ soybean oil and $30 \%$ fully hydrogenated soybean oil. Number of replicates for moisture gradient analysis: 4; Number of replicates for cracking analysis: 10; Statistical test: ANOVA and multiple comparison of means using Tukey's test; Degree of significance: $\mathrm{p} \leq 0.05$.

Table 5. The biscuits produced with the blends can be defined as zero trans, since the levels are in accordance with Resolution RDC 54 (BRASIL, 2012), which states that a product is free of trans fats when it has levels of up to $0.1 \mathrm{~g}$ of trans fats per serving (serving of $30 \mathrm{~g}$ for biscuits) and has a low content in saturated fats (up to $1.5 \mathrm{~g}$ of the sum of saturated fats and trans fats $/ 50 \mathrm{~g}$ - with respect to this issue, the legislation defines a serving of $50 \mathrm{~g}$ for products with a serving with $30 \mathrm{~g}$ or less, and with the energy from saturated fat being less than $10 \%$ of the total 
TABLE 5. Levels of total, saturated and trans fat (g/serving of $30 \mathrm{~g}$ ) of the biscuits produced with the different blends

\begin{tabular}{lccc}
\hline $\begin{array}{l}\text { Biscuits produced } \\
\text { with the blend }\end{array}$ & Total fat* & Saturated fat* & Trans fat* \\
\hline BLD1 & $2.46(4.10)$ & $0.78(1.30)$ & $0.02(0.03)$ \\
BLD2 & $2.46(4.10)$ & $0.78(1.30)$ & $0.02(0.03)$ \\
BLD3 & $2.46(4.10)$ & $0.84(1.40)$ & $0.02(0.03)$ \\
BLD4 & $2.46(4.10)$ & $0.79(1.32)$ & $0.02(0.03)$ \\
\hline
\end{tabular}

Between parentheses, contents for $50 \mathrm{~g}$ used to determine saturated + trans fat content, according to RDC 54 (BRASIL, 2012). *Considering a loss of $20 \%$ in the oven. Where: BLD1: $6 \% \mathrm{~B} 1+34 \% \mathrm{~B} 2+60 \% \mathrm{SO} ; \mathrm{BLD} 2: 13 \% \mathrm{~B} 1+19 \% \mathrm{~B} 2+68 \%$ SO BLD3: $24 \% \mathrm{~B} 1+9 \% \mathrm{~B} 2+67 \%$ SO BLD4: $0 \% \mathrm{~B} 1+$ $46 \%$ B2 + 54\% SO; B1: interesterified soybean-based fat with $40 \%$ soybean oil and $60 \%$ fully hydrogenated soybean oil; B2: interesterified soybean-based fat with $70 \%$ soybean oil and $30 \%$ fully hydrogenated soybean oil. Number of replicates of analysis: 4 .

energy value of the food). The maximum value of the sum of saturated and trans fats in $50 \mathrm{~g}$ of the biscuits produced with the blends is $1.43 \mathrm{~g}$, considering a loss in moisture of $20 \%$ in the oven.

\section{CONCLUSIONS}

Artificial Neural Networks were highly efficient in predicting the content of solid fat and the melting point of the blends elaborated to reach a profile similar to those of commercial fats. It was shown that it is possible to develop $100 \%$ soy-based low trans fats to be used in laminated biscuits. The blends presented a greater difference in the solid fat content between the temperatures of $10^{\circ} \mathrm{C}$ and $30^{\circ} \mathrm{C}$ when compared with commercial fats, due to the characteristics of the soy-based interesterified fats used.

The blends did not cause significant alterations in the technological characteristics of the biscuits, so it was possible to replace commercial fats and to produce biscuits of excellent quality with zero trans and low saturated fat contents.

This study permitted us to verify the potential of an Artificial Neural Network to formulate fats to be used in zero trans biscuits from a technological point of view. For future studies it is recommended to carry out a sensory test to confirm the acceptance of the formulations developed.

\section{ACKNOWLEDGEMENTS}

The authors would like to thank CNPq for the scholarships granted to Alessandra Afonso Teixeira Penteado and Amanda de Cássia Nogueira. They also thank Espaço da Escrita - Coordenadoria Geral da Universidade - UNICAMP - for the language services provided.

\section{REFERENCES}

American Association of Cereal Chemistry International (AACCI). 2010. Approved Methods of Analysis. AACC International, Saint Paul, USA.

American Oil Chemists'Society (AOCS). 2005. Official Methods and Recommended Practices of the American Oil Chemists' Society. American Oil Chemists' Society Press, Champaign, USA.

Bernussi ALM, Chang YK, Martínez-Bustos F. 1998. Effects of production by microwave heating after conventional baking on moisture gradient and product quality of biscuits (Cookies). Cereal Chem. 75, 606-611. https://doi. org/10.1094/CCHEM.1998.75.5.606

Block JM, Barrera-Arellano D, Almeida R, Gomide FC, Moretti RB. 2003. Formulación de grasas a través de redes neuronales: productos comerciales y producción en planta piloto. Grasas Aceites 54, 240-244. https://doi.org/10.3989/ gya.2003.v54.i3.237

Block JM, Barrera-Arellano D, Figueiredo M, Gomide FC. 1997. Blending process optimization into special fat formulation by neural networks. J. Am. Oil Chem. Soc. 74, 1537-1541. https://doi.org/10.1007/s11746-997-0073-5

Block JM, Barrera-Arellano D, Figueiredo M, Gomide FC, Sauer L. 1999. Formulation of special fats by neural networks: a statistical approach. J. Am. Oil Chem. Soc. 76, 1357-1361. https://doi.org/10.1007/s11746-999-0150-z

BRASIL.2012.Resoluçãon ${ }^{\circ}$ 4, de12 denovembrode2012. Regulamento técnico sobre Informação Nutricional Complementar. Diário Oficial da União, Brasília, BRA. https://portal.anvisa.gov. br/documents/33880/2568070/rdc0054_12_11_2012.pdf/ c5ac23fd-974e-4f2c-9fbc-48f7e0a31864

Cerqueira EO, Andrade JC, Poppi RJ, Mello C. 2001. Redes neurais e suas aplicações em calibração multivariada. Quím. Nova 24, 864 873. https://doi.org/10.1590/S0100-40422001000600025

Dhaka V, Gulia N, Ahlawat KS, Khatkar BS. 2011. Trans fats sources, health risks and alternative approach - A review. J. Food Sci. Technol. 48, 534-541. https://doi.org/10.1007/ s13197-010-0225-8

Doan CD, Tavernier I, Danthine S, Rimaux T, Dewettinck K. 2018. Physical compatibility between wax esters and triglycerides in hybrid shortenings and margarines prepared in rice bran oil. J. Sci. Food Agric. 98, 1042-1051. https:// doi.org/10.1002/jsfa.8553

Francis JF, Clydesdale FM. 1975. Food colorimetry, theory and application. Van Nostrand Reinhold/AVI, New York, USA.

Gandra KM. 2011. Formulação de gorduras zero trans para recheio de biscoitos utilizando redes neurais. Tese de Doutorado, Faculdade de Engenharia de Alimentos, Universidade Estadual de Campinas, Campinas, BRA.

Garcia RKA, Gandra KM, Barrera-Arellano D. 2013. Development of a zero trans margarine from soybean-based interesterified fats formulated using neural networks. Grasas Aceites 64, 521-530. https://doi.org/10.3989/gya.049113

Garcia RK, Gandra KM, Block JM, Barrera-Arellano D. 2012. Neural networks to formulate special fats. Grasas Aceites 63, 245-252. https://doi.org/10.3989/gya.119011

Ghotra BS, Dyal SD, Narine SS. 2002. Lipid shortenings: a review. Food Res. Int. 35, 1015-1048. https://doi. org/10.1016/S0963-9969(02)00163-1

Grimaldi R, Gonçalves LAG. 2009. Evolução da saudabilidade das gorduras "low trans/low sat" para massas de biscoitos. Food Ingredients Brasil 10, 28-31.

Hartman L, Lago RCA. 1973. Rapid preparation of fatty acid methyl esters from lipids. Lab. Pract. 22, 475-476.

Karabulut I, Turan S, Ergin G. 2004. Effects of chemical interesterification on solid fat content and slip melting point of fat/oil blends. Eur. Food Res. Technol. 218, 224-229. https:// doi.org/10.1007/s00217-003-0847-4

Lai H-M, Lin T-C. 2006. Bakery Products: Science and Technology, in Hui YH, Corke H, De Leyn I, Nip W-K, Cross N (Eds.) Bakery Products: Science and Technology. Blackwell Publishing, Ames, pp. 3-65. https://doi. org/10.1002/9780470277553.ch1

Manley D. 2000. Technology of biscuits, crackers and cookies. Woodhead Publishing, Cambridge, UK. https://doi.org/ $10.1533 / 9781855736597$ 
Moretto E, Fett R. 1999. Processamento e análise de biscoitos. Varela, São Paulo, BRA

Pareyt B, Delcour JA. 2008. The role of wheat flour constituents, sugar, and fat in low moisture cerealbased products: a review of sugar-snap cookies. Crit. Rev. Food Sci. Nutr. 48, 824-839. https://doi. org/10.1080/10408390701719223

Penteado AAT, Steel CJ. 2009. Avaliação de parâmetros de qualidade de biscoitos tipo Maria do mercado brasileiro. Simpósio Latino Americano de Ciência de Alimentos. UNICAMP, Campinas, BRA
Ribeiro APB, Moura JMLN, Grimaldi R, Gonçalves LAG. 2007. Chemical interesterification: alternative to production of zero trans fats. Quím. Nova 30,1295-1300. https://doi. org/10.1590/S0100-40422007000500043

Smith WH. 1972. Biscuits, crackers \& cookies: technology, production \& management. MFI, New York, USA.

Sousa EA, Teixeira LCV, Mello MRPA, Torres EAFS, Neto JMM. 2003. Application of neural network for evaluation of the amount of mechanically deboned poultry meat in sausage. Food Sci. Technol. 23, 307-311. https://doi.org/10.1590/ S0101-20612003000300002 